\title{
Determinants of Market outlet choices by smallholder chickpea farmers in Estie district Amhara Region, Ethiopia
}

\author{
By Chernet worku, marlign adugna, essa chanie \\ ${ }^{1^{*}}$ Department of Agribusiness and Value chain Management, Debre markos university Burie \\ Campus, Debre Markos, Ethiopia; \\ chernetworku49@gmail.com \\ ${ }^{2}$ Department of agricultural Economics, university of Gondar, Gondar Ethiopia; \\ Mryk3@gmail.com \\ ${ }^{3}$ Department of agricultural Economics, university of Gondar, Gondar Ethiopia; \\ essachanie@gmail.com
}




\begin{abstract}
In Ethiopia, chickpea is an important plus crop, particularly in Estie district. It is a source of food and provides cash income for majority of smallholder farmers. To commercialize chickpea producers, selecting an appropriate market channel is mandatory. However, selecting an appropriate market channel is not an easy task because there are different factors that affect market outlet choices in the district. Hence, this study aimed to identify factors that affecting chickpea market outlet choices. Both primary \& secondary sources of data were used. A two-stage random sampling procedure was used and a total of 122 smallholder farmers were randomly and proportionally selected to collect primary data. Multivariate probit model was employed to identify factors affecting chickpea market outlet choices. The result shows that five major chickpea marketing channels were identified and among them wholesalers and retailers purchased about (61.84\%) and (18.2\%) respectively. The estimation result of multivariate probit model showed that the likelihood of sampled households to select collectors, consumers, retailers and wholesalers were 25.3\%, 35.4\%, 30.5\% and 36\%, respectively. The joint probability of success and failure to select all market outlets was $0.01537 \%$ and $13.4 \%$ respectively. It also indicated that sex of household, education status, family size, off-farm income, access to credit; lagged price and distance to market significantly affected the market channel choice decision of producers. Based on the findings, Government and concerned stakeholders need to focus more on enhancing accessibility of infrastructures facilities, strengthening credit access and improving yield through extension service to accelerate selecting appropriate market channel.
\end{abstract}

Keywords: Market outlet choice, chickpea, multivariate probit 


\section{INTRODUCTION}

The agricultural sector is the most important sector in the Ethiopian economy that features strongly in the overarching economic policy of the country - agricultural development led industrialization (ADLI). It becomes source of income and employment for the majority of the country's population. Currently, agriculture contributes over 35.8\% to the national GDP, almost 90 percent of export and 72.7 percent of employment (CIA, 2018).

Ethiopia is the leading producer, consumer and seller of chickpea among Africa country, and is the sixth most important producer in the world. Ethiopian chickpea production is shifting from traditional cultivars to improved varieties and from desi variety to the kabuli variety. Kabuli is high yield with relative to desi varieties. Other progressive shifts include the use of marketoriented cultivars and enhanced adoption of production packages recommended by research. among which pulling back planting time to late July - early August depending on soil drainage helped much in increasing productivity through provision of longer growing time( Mekasha ,2013).

According to Mitiku (2011) crop type factor considerably influence farm-gate price. Farmers particularly in Ethiopia do not get enough benefit from income of chickpea sales mainly due to the predominance of low value local Desi types or variety. The grains marketing system is generally characterized by low volume, lack of effective demand for the product, and low awareness about market preferred chickpea varieties replacement thereby hindering the uptake of these profitable varieties. Thus, the supply in the market of these high values Kabuli chickpea types are in very limited quantities and from several highly dispersed small producers.

In order to maximize the share and increase benefit the producers make appropriate decision as well as sell for best channel but in the district producers are not selling their produce in an organized manner and they are not benefited due to different factors. Therefore, identifying these factors is very important in terms of pinpointing possible interaction that help producer to maximize the profit, benefit and to choice best channel. The study was aimed to analyze and identify determinants of market outlet choice decisions of chickpea producers as well as designed to address the existing information gap that benefit producers. 


\section{RESEARCH METHODOLOGY}

\subsection{Description of the Study Area}

Este is located around $653 \mathrm{~km}$ northwest of Addis Ababa and about $114 \mathrm{~km}$ east of Bahir Dar. Este is bordered by the Abay River on the south which separates it from the East Gojjam Zone, on the west by Andabet and Dera, on the northwest by Fogera, on the northeast by Lay Gayint, on the east by Simada, and on the north by Farta. In the study woreda there are 46 Kebele administrations (KAs) with four urban kebele and forty two rural kebeles. From a total forty two KAs 11 are potential chickpea producer kebeles in the study woreda.

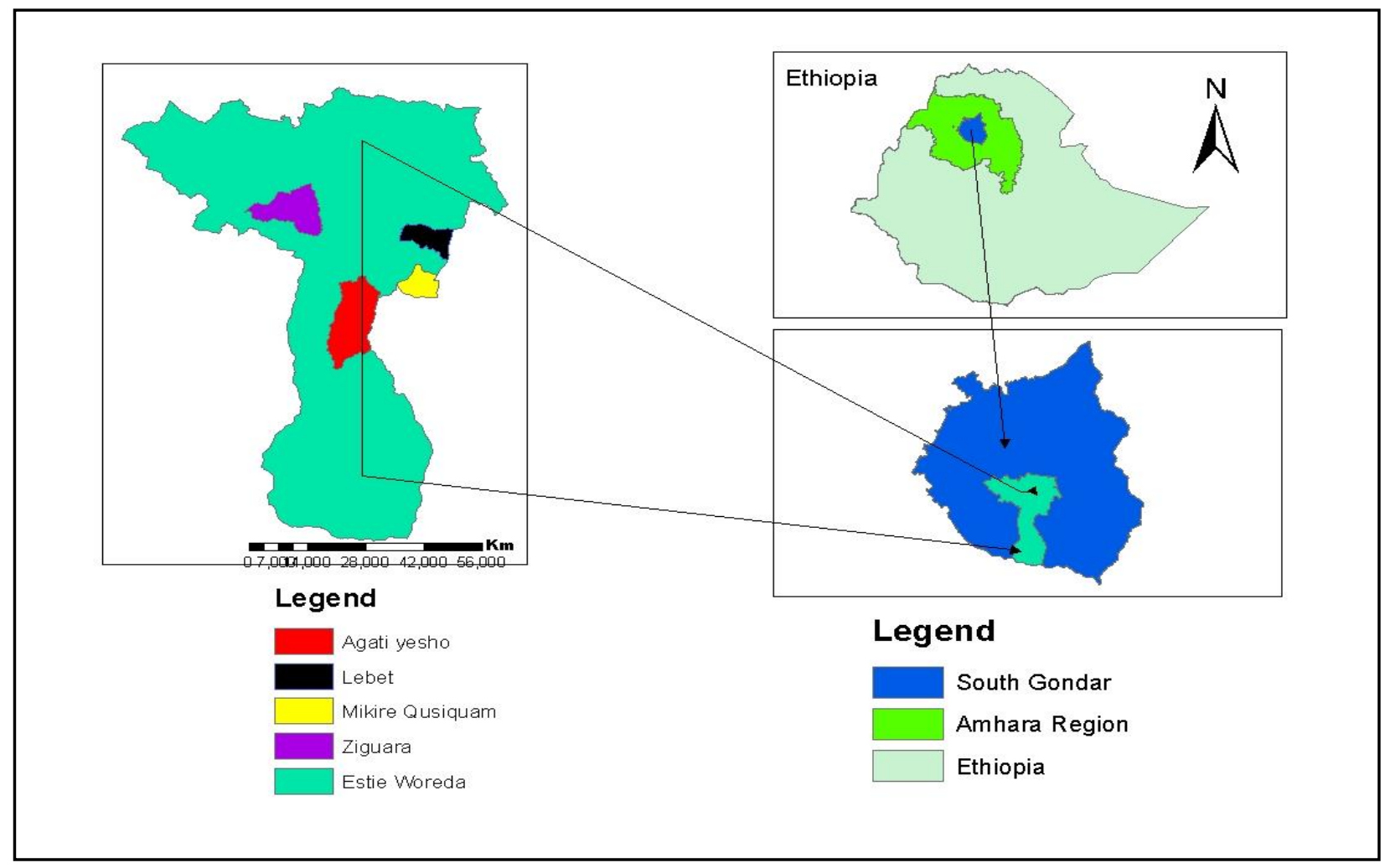

Figure 1.Map of the study area

The altitude of the woreda ranges from 1500-4231 meter above sea level (m.a.s.l.) and receives mean annual rainfall of $1403.85 \mathrm{~mm}$, which occurs mainly in the June, July, August and September. Other months of the year are almost dry with erratic rainfall. The average daily temperature ranges from 8.3- $25 \mathrm{C}$. Moreover, the brown soils are the dominant soil type which is $60 \%$ the other $40 \%$ is red $(30 \%)$ and black soil is $10 \%$ and it is moderately fertile. The agro 
ecological condition of the study area accounts for $50.8 \%$ woyina dega (mid highlands), Dega (highland) for $44.12 \%$, Wurch (frosty weather) for $3.48 \%$ and the rest $1.6 \%$ accounts kolla. In general, the weather condition is a hospitable environment for the moderately dense population which is $52.8 \%$ in woyina dega, $29.6 \%$ in Deg, $2.4 \%$ in Wurch and for $15 \%$ in kolla (EWOA, 2019).

Based on the 2015 national census conducted by the CSA of Ethiopia, East Este woreda had a total population of 210,825 , whom 107,555 are men and 103,270 women; 13,901 or $6.59 \%$ are urban inhabitants. The majority of the population practiced Ethiopian Orthodox Christianity, with $97.08 \%$ reporting that as their religion and the remaining $2.91 \%$ of the population said they were Muslim.

Wheat, Teff, barley and Maize are the dominant and most important crops, serving as both the main food and cash crops. Other cash crops grown in the study area includes pea, chickpea, Nouge and Beans. In the study area different fruits are grown. These include banana, mango, avocado, orange and lemon is the major fruit crop. Crop sales make the largest contribution to the household income together with sheep and goat for their cash earnings. Cattle, sheep, goats, donkeys, horses, honeybee production and chickens are the most reared livestock. Cattle and sheep are free-grazers at the grazing land and given complementary crop, residues at the dry season whilst chicken are scavengers and partly feed grain. Livestock are a significant source of income, mostly obtained from the sale of sheep and goats (EWOA 2019).

\subsection{Types, Sources and methods of Data Collection}

Both quantitative and qualitative data were collected from primary and secondary data sources. Primary data was collected from respondents (sampled households, collectors, district retailers and wholesalers) through semi-structured questionnaire. Focus group discussion and field observation were also undertaken during primary data collection in the study area. Farmers and extension agents were interviewed through focus group discussion using a checklist. Secondary data was collected from office of agriculture, woreda trade office, survey report, annual report and websites. Both published and unpublished documents were comprehensively reviewed to support interpretation of the primary data. 


\subsection{Sample Size and Sampling Techniques}

The target populations for this study were smallholder chickpea producers and traders (wholesalers, retailers and collector) along the chickpea market chain. The sample for this study was drawn from chickpea producing households and chickpea traders. Two stage sampling procedure were used for the selection of sample household heads. At the first stage, from a total of 11 chickpea producing kebeles of the district, 4 chickpea producing kebeles were selected randomly. These are Mikire Qusequam, Ziguara, Agati yesho and Lebete. In the second stage, from the selected kebeles, about 122 sample households were selected from the selected four kebeles by using simple random sampling technique taking into account probability proportional to size of each sample kebele (see Table 1 below). The sample size of rural households was determined by using the following formula developed by Yamane, (1967).

$\mathrm{n}=\frac{\mathrm{N}}{1+\mathrm{N}(\mathrm{e}) 2} \quad \mathrm{n}=\frac{8,690}{1+8,690(0.09) 2}=122$

\section{Where:}

$\mathrm{n}=$ is the sample size 122 ,

$\mathrm{N}=$ total population 8,690

$\mathrm{e}=$ is the level of precision 0.09

Data from traders also was collected. According to the information obtained from the trade

office, there were only 4 licensed wholesalers. So, census survey was conduct for wholesalers. But due to lack of clear data in the district about how many retailers involved in chickpea trade, a market assessment survey was conducted to come up with clear pictures of retailers engaged in chickpea trading activity in the study area. Then, 7 retailers from district market and 5 retailers from village market as well as 9 collectors were selected purposively during the market day constituting a total of 25 traders were interviewed.

\subsection{Methods of Data Analysis}

\subsubsection{Descriptive analysis}

Descriptive statistics such as frequency, mean, standard deviation and percentage were used to analyze the characteristics of the sample households and traders. Furthermore, the constraints 
which affect chickpea production and marketing of chickpea market were analyzed using descriptive statistics.

\subsubsection{Econometric analysis}

Multinomial models are suitable when individuals can choose one outcome only among set of collectively exhaustive, mutually exclusive alternatives (Gumataw et al., 2013). However, in this study market outlet choice of producers' are not mutually exclusive; considering the possibility of simultaneous choices of channel and the possible correlations between these market outlet choice decisions. Since, chickpea is a cash crop in the study area and the overall market contexts may compel producers to choose more than two outlets simultaneously. The multivariate probit model takes into account such potential interdependence in market outlet choices and the possible correlation in the choice of alternative outlets. The multivariate probit model is regression model that simultaneously estimates the influence of independent variables on one or more than one dependent variables, and allows for the error terms to be freely correlated. The dependent variable symbolizes 1 (if chosen) or 0 (otherwise) responses to the question regarding the importance of each factor on outlet choice. Multivariate probit approach simultaneously models the manipulate the set of independent variables on choice of markets outlet, while permitting for the probable correlations between unobserved disturbances, as well as the relationships between the choices of diverse market outlet (Belderbos et al., 2004).

It is assumed that a given producer $\mathrm{i}$ in decision making considering not exclusive alternative that constituted the choice set $\mathrm{K}^{\text {th }}$ of chickpea marketing outlets, the choice sets may differ according to the decision maker for exploiting his/her utility and profit. Let Uo stand for the benefits to the farmer who chooses wholesalers, and let Uk represent the benefit of farmer to choose the $\mathrm{K}^{\text {th }} \quad$ market channel: where $\mathrm{K}$ denotes choice of wholesalers (X1), retailers (X2), collectors (X3) and consumers (X4). The farmer decides to choose the $\mathrm{K}^{\text {th }}$ market outlet if $\mathrm{X}^{*} \mathrm{ik}$ $=\mathrm{UK}-\mathrm{UO}>0$. The net benefit $\mathrm{X}^{*} \mathrm{ik}$ that the farmer derives from choosing a market outlet is a latent variable determined by observed explanatory variable $(\mathrm{Zi})$ and the error term $(\varepsilon i)$ :

$\mathrm{X} * \mathrm{ik}=Z i \beta \mathrm{k}+\varepsilon \mathrm{i} \quad \mathrm{K}=(\mathrm{X} 1, \mathrm{X} 2, \mathrm{X} 3, \mathrm{X} 4)$

Using the indicator function, the unobserved preferences in the above equation translates into the observed binary outcome equation for each choice as follows: 
$\mathrm{X} i k=\left\{\begin{array}{l}1 \text { if } \mathrm{X} * \mathrm{ik}>0 \mathrm{~K}=(\mathrm{X} 1, \mathrm{X} 2, \mathrm{X} 3, \mathrm{X} 4) \\ 0 \quad \text { otherwise }\end{array}\right.$

Where Xi1 $=1$, if farmers choose wholesale $(0$ otherwise $), \mathrm{Xi} 2=1$, if farmers choose retailer $(0$ otherwise), $\mathrm{Xi} 3=1$, if farmers choose collector ( 0 otherwise) and $\mathrm{Xi} 4=1$, if farmers choose consumer (0 otherwise).

In multivariate model, where the choice of a number of market outlets is possible, the error terms mutually follow a multivariate normal distribution (MVN) with a mean of zero and variancecovariance matrix $\mathrm{V}$ has values of 1 on the leading diagonal and correlation $\rho j \mathrm{k}=\rho \mathrm{kj}$ as offdiagonal element where $(\mu \times 1, \mu \times 2, \mu \times 3, \mu \times 4) \operatorname{MVN} \sim(0, \Omega)$ and the symmetric variancecovariance matrix $\Omega$ is specified by:-

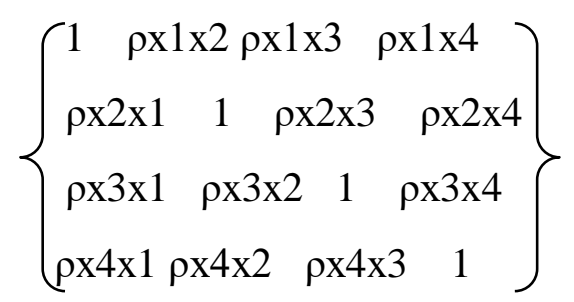

Pursue the outline used by Cappellari and Jenkins (2003), the log-likelihood function related with a sample result is then given by;

$\mathrm{L}=\sum_{i=0}^{n} \omega \ln \Phi \mathrm{i}(\mu i, \Omega)$

Where $\omega$ is an optional observation weight of i. . . N and $\Phi$ is the mv standard normal distribution with point of view $\mu$ i and $\Omega$, where $\mu$ i can be denoted as:

$\mu \mathrm{i}=\left(\mathrm{K}_{\mathrm{i} 1} \beta{ }_{1} \mathrm{X}_{\mathrm{i} 1}, \mathrm{~K}_{\mathrm{i} 2} \beta_{2} \mathrm{X}_{\mathrm{i} 2}, \mathrm{~K}_{\mathrm{i} 3} \beta 3 \mathrm{X}_{\mathrm{i} 3}, \mathrm{~K}_{\mathrm{i} 4} \beta 4 \mathrm{X}_{\mathrm{i} 4}\right)$, while $\Omega_{\mathrm{ik}}=1$ for $\mathrm{J}=\mathrm{K}$ and

$\Omega \mathrm{jk}=\Omega \mathrm{kj}=\mathrm{KijKik} \rho \mathrm{jk}$ for $\mathrm{J}=\mathrm{K}, \mathrm{K}=1,2,3 \ldots$ with $\mathrm{kik}=2 \mathrm{Xik}-1$ for each $\mathrm{i}, \mathrm{k}=1 \ldots 4$.

Matrix $\Omega$ has element essentials $\Omega \mathrm{jk}$, Therefore, to use multivariate probit model to study producers joint-decision to market outlet choice. 


\section{RESULT AND DISICUSSION}

\subsection{Descriptive Statistical Analysis}

The results in Table 1 indicate that $88.6 \%, 86.2 \%, 86.2 \%$ and $93.2 \%$ of the male headed households used Wholesaler, Retailer, Collector and Consumer, respectively as a choice of marketing outlets. On the other hand, $11.1 \%, 13.8 \%, 31 \%$ and $6.9 \%$ of the female headed households used Wholesaler, Retailer, Collector and Consumer, respectively as the choice of marketing outlets. This showed that the male headed households who used, Wholesaler and Consumer as the choice of marketing outlets were more than other actors. This implies that the male headed households are likely to choice Wholesaler and Consumer marketing outlets.

Off-farm income: As indicated in Table (1) availability of off-farm income choosing wholesaler outlet as compared to other outlet. This implies that farmers who have off-farm income have less possibility to choose collector outlet as compared to those who have no access to off-farm income because of producers with availability of off-farm income had capacity to transport their product to the nearest markets and sold to the best alternative outlets.

Table.1 Characteristics of chickpea producers in relation to choice of market outlet

\begin{tabular}{llcccc}
\hline Characteristics & Item & \multicolumn{4}{c}{ Frequency and percentage } \\
\cline { 3 - 6 } Sex & Male & $(31) 88.6 \%$ & $(25) 86.2 \%$ & $(20) 69.0 \%$ & $(27) 93.1 \%$ \\
& Female & $(4) 11.4 \%$ & $(4) 13.8 \%$ & $(9) 31.0 \%$ & $(2) 6.9 \%$ \\
\multirow{2}{*}{ Off-farm Income } & yes & $(10) 28.6 \%$ & $(7) 24.1 \%$ & $(7) 24.1 \%$ & $(6) 20.7 \%$ \\
& no & $(25) 71.4 \%$ & $(22) 75.9 \%$ & $(22) 75.9 \%$ & $(23) 79.3 \%$ \\
\multirow{2}{*}{ Transport facility } & yes & $(11) 31.4 \%$ & $(3) 10.3 \%$ & $(7) 24.1 \%$ & $(10) 34.5 \%$ \\
& no & $(24) 68.6 \%$ & $(26) 89.7 \%$ & $(22) 75.9 \%$ & $(19) 65.5 \%$ \\
\multirow{2}{*}{ Market information } & yes & $(26) 89.7 \%$ & $(26) 74.3 \%$ & $(22) 75.9 \%$ & $(25) 86.2 \%$ \\
& no & $(3) 10.3 \%$ & $(92) 5.7 \%$ & $(7) 24.1 \%$ & $(4) 13.8 \%$ \\
\hline
\end{tabular}

Source: Own survey result, 2019

The results in Table 1 on transport ownership indicate that $31.4 \%, 10.3 \%, 24.1 \%$ and $34.5 \%$ of market participants used Wholesaler, Retailer, Collector and Consumer, respectively as the choice of marketing outlets. This means that the majority of those who sold at Wholesaler and Consumer outlet that owned transportation. In terms of market information, the results reveal that $89.7 \%$ and $86.2 \%$ of the market participant, who sold at Wholesaler and Consumer market 
outlet, respectively had an access to market information. This implies that the majority of market participants who sold at Wholesaler and Consumer had an access to price information. Price information aids in acquainting the market participants with the pricing conditions.

\subsection{Chickpea market channels}

The analysis of marketing channels proposed to provide information on the follow of goods and service from their producer to the final consumer. Chickpea producers in the study area used different channel to distribute and sale their product. According to the survey result, five marketing channels were identified for chickpea market chain in the study area. This channel comparison made based on the volume pass through. Both wholesaler and retailers were the major purchasers of chickpea from producers in the study area. The main marketing channel identified from the point of production until the product reaches to the final consumer through different intermediaries were:

Channel 1: Producer $\longrightarrow$ Consumer $(9.41 \%)$

Channel 2: Producer $\longrightarrow$ Retailer $\longrightarrow$ Consumer $(18.2 \%)$

Channel 3: Producer $\longrightarrow$ Wholesaler $\longrightarrow$ Consumer $(28.46 \%)$

Channel 4: Producer $\longrightarrow$ Collector $\longrightarrow$ Wholesaler $\longrightarrow$ Consumer $(10.55 \%)$

Channel 5: Producer $\Longrightarrow$ wholesaler $\Longrightarrow$ Regional traders (33.38)

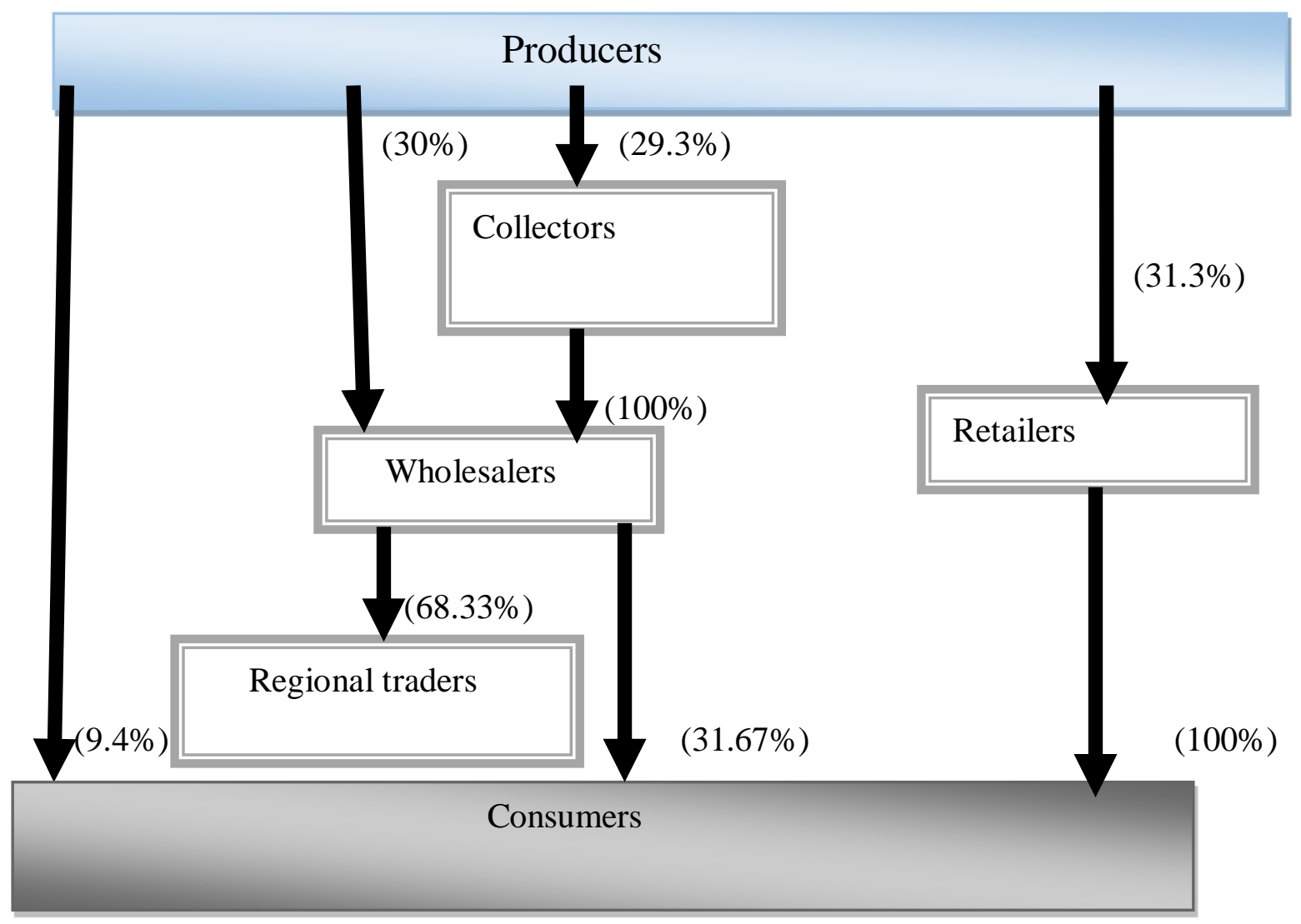


Figure 2 : Chickpea marketing channel

Source: Own survey result, 2019

As can observed in the figure above the producer sale their product to wholesaler, retailer, collector, and consumer with (61.84\%), (18.2\%), (10.55\%), and (9.41\%) respectively. Accordingly, from a total amount of chickpea supplied to the market the largest and the lowest volume of chickpea passed through channel 5 and 1 respectively. In the district the flow of chickpea was more concentrated mostly on retailers and wholesalers and less on collectors and consumers.

\subsection{Econometrics Analysis}

\subsubsection{Factors affecting chickpea Market Outlet Choices}

The farmers who produce chickpea and participate in chickpea market have four alternative market channels in Este district. These are Wholesalers, Retailers, Collectors and Consumers. The multivariate probit model was used to determine the factors influencing chickpea marketing channel choice in Este district. The variable used in the estimation were: sex, education, family size of household, total livestock unit, Farm size, quantity of chickpea produced, off-farm income farming experience, frequency of extension contact, access to market information, lagged price, distance to market, access to credit as presented in Table (2) below.

The result shows that Wald test (Wald $(\chi 2(60)=113.47, \mathrm{p}=0.0000)$ is strongly significance at $1 \%$ probability level, which implies that the subset of coefficient of the model is jointly significance and that the explanatory power of the factors include in the model is satisfactory, thus, the multivariate probit model fits the data reasonably well. The simulated maximum likelihood estimation result $(\operatorname{LR}(\chi 2(6)=29.7787$ Prob $>$ chi2 $=0.0000$ of the null hypothesis of independence between the market outlets decision $(\rho 21=\rho 31=\rho 41=\rho 32=\rho 42=\rho 43=0)$ is significance at $1 \%$ significance level. Therefore, the null hypothesis that all the $\rho$ (Rho) values are jointly equal to 0 is rejected, this indicate the goodness-of fit of the model and supporting the use of MVP model over individual probit model. This proves that separate estimation of choice decision of these outlets is biased, and the decisions to choose the four chickpea marketing outlets are interdependent. 
As the simulated maximum likelihood (SML) estimation result indicated that in Table (2) the marginal success probability of each market outlets is present. The probability of choosing consumers market channel which is $36 \%$ was high relatively as compared the probability of choosing retailers market channel (30\%), collectors' market channel $(25 \%)$ and consumers' market channel (35\%). The joint probability of success and failure of choosing all market outlets was only $.0154 \%$ whereas the probability of jointly failure was $13.4 \%$.

Table 2: Probability, overall fitness and correlation matrix of market outlet in MVP model

\begin{tabular}{|c|c|c|c|c|}
\hline \multicolumn{5}{|c|}{ Market outlet } \\
\hline Variable & Wholesaler & Retailer & Collector & Consumer \\
\hline Probability of selecting & 0.36 & 0.305 & 0.253 & 0.354 \\
\hline Joint probability (success) & & & & .0001537 \\
\hline Joint probability (failure) & & & & .1340651 \\
\hline Simulation draws & & & & 5 \\
\hline Observation & & & & 122 \\
\hline Log likelihood & & & & -206.13559 \\
\hline Wald $(\chi 2(60))$ & & & & 113.47 \\
\hline Prob $>\chi 2$ & & & & $0.0000 * * *$ \\
\hline \multicolumn{5}{|c|}{ Estimated correlation matrix } \\
\hline & $\rho 1$ & $\rho 2$ & $\rho 3$ & $\rho 4$ \\
\hline$\rho 1$ & 1.0000 & & & \\
\hline$\rho 2$ & $-.325 * *(-0.261)$ & 1.0000 & & \\
\hline$\rho 3$ & $-.532 * * *(-0.310)$ & $-.456 * *(-0.119)$ & 1.0000 & \\
\hline$\rho 4$ & $-.020(-0.005)$ & $-.023(-0.090)$ & $-.202(-0.333)$ & 1.0000 \\
\hline The likelihood ratio test & $\rho 21=\rho 31=\rho 41$ & $\begin{array}{r}1=\rho 32=\rho 42= \\
\quad \chi 2(6)=29.77 \\
\quad \text { Prob }>\chi 2=0.0\end{array}$ & $\begin{array}{l}\rho 43=0: \\
87 \\
000\end{array}$ & \\
\hline
\end{tabular}

Note: $* * *$, and $* *$ are statically significance at 1 , and $5 \%$ significance level respectively.

Source: Own survey result, 2019

The $\rho$ value clarifies the degree of correlation between the dependant variable or each market channel level. As the result indicates that three values were statistically significance and all are negatively correlated. The $\rho 21$ (correlation between the choice of retailer and wholesaler channel) is negatively and statistical significant at 5\% significance level. The $\rho 32$ (correlation between the choice of collector and retailer channel) is negatively and statistical significant at 
$1 \%$ significance level. The $\rho 31$ (correlation between the choice of collectors and wholesaler channel) is negatively and statistical significant at 5\% significance level. Generally this implies that the farmers involved in one market channel less likely supply or involved to other market channel.

As depicted in the Table (3) out of thirteen explanatory variables include in multivariate probit model three variables significantly affected wholesalers outlet at different significance level, two variables significantly affected retailers outlet at different significance level, four variables significantly affected collectors outlet at different significance level and five variables significantly affected consumers outlet at different significance level.

Table 3: Multivariate probit estimation result for determinant of market channel choice

\begin{tabular}{lllllllll}
\hline Variable & \multicolumn{2}{l}{ Wholesaler } & \multicolumn{3}{l}{ Retailer } & \multicolumn{3}{c}{ Collector } \\
\cline { 2 - 8 } SEX & Coef. & Se. & Coef. & Se. & Coef. & Se. & Coef. & Se. \\
EDUHH & .353 & .394 & .498 & .447 & $-1.084 * *$ & .424 & .290 & .533 \\
Read and write & .199 & .290 & .084 & .302 & 033 & .393 & $1.315 * * *$ & .348 \\
primary & -.166 & .502 & .358 & .534 & -.710 & .609 & $1.901 * * *$ & .584 \\
Secondary & $1.657 * * *$ & .568 & -.964 & .885 & -.600 & .605 & 1.035 & .635 \\
FYSIZE & .075 & .067 & -.097 & .067 & -.012 & .082 & $-.250 * * *$ & .092 \\
TLU & .053 & .094 & -.040 & .099 & -.039 & .123 & -.129 & .107 \\
FARMSIZE & .317 & .229 & -.205 & .249 & .267 & .274 & .390 & .254 \\
CHPPROD & -.038 & .065 & -.007 & .072 & -.025 & .087 & -.027 & .074 \\
OFFFARMN & $.924 * * *$ & .313 & -.042 & .321 & $-1.069 * *$ & .460 & $1.029 * *$ & .383 \\
EXPCE & -.018 & .014 & -.007 & .012 & -.018 & .013 & .004 & .015 \\
EXTCO & -.134 & .097 & .122 & .090 & -.137 & .103 & 058 & .111 \\
MRKINFO & -.287 & .382 & .004 & .386 & 1.074 & .521 & 457 & .464 \\
PRICE & $.182 *$ & .104 & $-.340 * * *$ & .108 & $-.515 * * *$ & .136 & $.225 *$ & .125 \\
DISMKT & .001 & .004 & .003 & .004 & -.007 & .005 & $-.008 *$ & .005 \\
CREDIT & 039 & .307 & $-.571 *$ & .318 & .553 & .370 & .124 & .369 \\
COns & $-4.242 * *$ & 1.981 & $5.713 * * *$ & 2.009 & $9.073 * * *$ & 2.669 & $-4.392 *$ & 2.428 \\
\hline NOte: ***3 & & & & & & & & \\
\end{tabular}

Note: $* * * * *$ and $*$ are statically significance at 1,5 and $10 \%$ significance level respectively. Source: Own survey result, 2019

Sex of household: As the result indicates sex of the household affect the market channel choice of collectors negatively and significantly at 5\% probability level. This implies that male headed household had a higher probability of selling for other channel and less probability of selling 
collectors channel as compared to female headed household and vice versa. This result in line with the finding of Rizik et al. (2015) and Jafar et al. (2017) in which sex of the household headed had significance effect on the choice of market channel on African indigenous vegetable and ground net respectively.

Education of the household: As indicated in Table (3) education status has positive significance association with the probability of choosing consumers outlet at $1 \%$ significance level whereas positively significance association with the probability of choosing wholesalers outlet at $1 \%$ significance level respectively. This implies that farmers who attained secondary school more likelihood to choose wholesalers whereas who can read and write as well as who attained primary school more likelihood to choose consumers' outlet as compared to those who did not read and write because of producers to attained secondary school and primary school had capability to receive market information and transport their product to the markets and sold to the best alternative outlets. This result is in line with Gizachew (2018) who reported that more educated farmers was more likely to sell pepper through wholesalers because more educated farmers may want to spend less time on doing marketing activities.

Family size of the household: Family size is negatively and significantly associated with selling chickpea to consumers at $1 \%$ significance level. This result shows that those households with large family size are less likely to choose consumer outlet. This may imply large household size is an indicator of requires larger amounts for consumption which enables farmers to sell small amount to consumers. This result is in line with Chala and Chalchisa (2017) they reported that family size negatively affected the choice of retailer channel.

Off-farm income: As indicated in Table (3) availability of off-farm income has negative significance association with the probability of choosing collector outlet at $5 \%$ significance level whereas positively significance association with the probability of choosing wholesalers and consumers outlet at $1 \%$ and $5 \%$ significance level respectively. This implies that farmers who have off-farm income have less possibility to choose collector outlet as compared to those who have no access to off-farm income because of producers with availability of off-farm income had capacity to transport their product to the nearest markets and sold to the best alternative outlets. This result is in line with Addisu (2016) who reported that off-farm income negatively affected the choice of rural collector channel. 
Access to credit: The variable was negatively and significantly associated with the retailers' outlet choice at $10 \%$ significance level. The negative and significance result implies that the house hold who gets credit less likely to deliver chickpea to the retailers outlet. The study by Chala and Chalchisa (2017) similar with this result that access to credit services affect negatively the choice of retailer channel.

Lagged price: chickpea price show that a significance positive correlation with wholesalers and consumers at $10 \%$ significance level whereas negatively correlation with retailers and collectors at $1 \%$ significance level. This implies that households receive high price from wholesalers and consumers channel and low price from retailers and collectors. This result is in line with Addisu (2016) also confirmed that price is associated with negatively and significantly at 5\% significance level of probability choice of retailer channel.

Distance to market: The result revealed that, distance to the nearest was negatively and significantly associated with the likelihood of choosing consumer outlet at $10 \%$ significance level. Household whose residences are far from the nearest markets are less likely to sell their product to consumer outlets. Therefore, most of the consumers are live in woreda market producers who found away from nearest market can less likely to sell their product to this channel since there is no road and transport facility to transport chickpea in the woreda market. The result is similar with the finding of Yaregal (2018) who found distance to nearest market has significance and negatively affected the preference of farmers to sell their product to wholesalers, consumer and processors. Addisu (2016) also confirmed distance to nearest market has significance and negatively affected the preference of farmers to sell their product to wholesalers. 


\section{CONCLUSION AND RECOMMEDATION}

The variables like sex of household, education status, household family size, off-farm income, access to credit, lagged price and distance to market significantly affected the market channel choice decision of producers. Therefore these variables require exceptional attention to increase farmer's margin from chickpea production and marketing so special focus need to be on these factors.

Finally, the implication of the study is targeting the producers' enhancement of education level, improving extension and credit services, establishing transport facility so as to increase the producers bargaining power and accessing better production methods are a means for better in selecting the best marketing outlet.

The multivariate probit model results revealed that producers have been significantly influenced by different factors in choosing appropriate marketing outlets to sell their chickpea produce and chickpea farmers were able to access collector, wholesaler, Consumer and retailer channels. By considering these factors provision of education and services to the producers on different chickpea marketing channels were key in accessing the best marketing channel for increasing the farmers' profit margin.

Farmers who live relatively far from the market are unlikely to sell to consumers suggesting the importance of adequate transportation services to enhance farmers to sell their chickpea based on their decision to choose the best channel. The study also pointed out that the level of education affected consumer outlets positively. Therefore, increasing awareness of households about the importance of adult education and about the school age at which their children should join the school for better marketing of chickpea and increase the quantity of chickpea sold at the most profitable market outlet. In addition to this, off- farm income positively influenced consumers out let and wholesaler outlet choice as well as access of credit negatively affected retailer outlet choice. Therefore, strengthening off- farm income is an implement strategy to enhance farmers to sell their produce through choosing the best outlet. Generally, concerned stakeholders need to focus more on enhancing accessibility of infrastructures such as road, market and transportation facilities to promote marketing of chickpea and increase marketed surplus. 


\begin{abstract}
Abbreviations
ADLI: Agricultural development led industrialization, GDP: gross domestic product, KAs :Keble administrations, EWOA: Estie woreda office of agriculture, SML: simulated maximum likelihood

Acknowledgements

The author would like to thank the Debre Markos University since financial support for this research was obtained from Debre Markos University. Moreover, we thank enumerators, the data respondents and district experts for their valuable response during data collection process.
\end{abstract}

Authors' contributions

All authors are read and approved final manuscript.

Funding

Debre Markos University provided financial support to complete this research successfully.

Availability of data and materials

The author wants to declare that they can submit the data at any time based on publisher's request. The datasets used and/or analyzed during the current study will be available from the author on reasonable request.

Ethics approval and consent to participate

Ethical clearance letters were collected from Debre Markos University research and community service directorate and Estie district of face to care for both the study participants and the researchers. During survey, of facial letter was written for the study, District informed verbal consent was obtained from each customer, and confidentiality was maintained by giving codes for each samples rather than recording their name. Study participants were informed that customer have a full right to discontinue or refuse to participate in the study. Hence, all participants throughout the research, including survey enumerators, households, the supervisors and key informants were fully informed of the objectives of the study. They were approached pleasantly in free moods until then do this research.

Consent for publication

Not applicable

Competing interests

The researcher declares that they have no competing interests. 


\section{REFERENCE}

Addisu Hailu. 2016. Value chain analysis of vegetables: the case of Ejere Woreda Oromia Region, Ethiopia. MSc Thesis. Haramaya University, Ethiopia.

Chala Hailu and Chalchisa Fana. 2017. Determinants of market outlet choice for major vegetable crop: Evidence from smallholder Farmers of Ambo and Toke-kutaye district, Oromia Region, Ethiopia. International Journal of agricultral marketig,4,161-169.

CIA (Central Intelligence agency). 2018. the work of nation, Ethiopia economy profile 2018. CIA World fact book, January 20, 2018 .

Belderbos,R., M., Diederen, B. Lkshin, B. and Veugelers R. 2004. R and D cooperation strategies hetrogeneity. Internationa Journal of Industrial Organization, 22, 1237-1263.

EWOA (Este Woreda Office of Agriculture). 2019. Este Woreda unpublished Report, August 20, 2019 unpublished.

Gizachew Wosene. 2018. Analysis of red pepper value chain: the case of Wenberma Woreda Amhara Region, Ethiopia. MSc Thesis. Haramaya University, Ethiopia.

Gumataw K.A., Jos B., Stefano P. and Onno O. 2013. Adoption of improved potato varieties in Ethiopia: the role of agricultural knowledge and innovation system and smallholder farmers quality assessment. Agricultural system, 22-32.

Jafer Ahmed, Abdulaziz Umare, Nasir Mahamed, Oromia Galane and Kebret Desse. 2017. Factors affecting groundnut market outlet choice in moisture stress area of Babile District, Eastern Ethiopia. International Journal of Agricultural Science, Research and Technology in Extension and Education Systems (IJASRT in EESs), 7(2): 91-101.

Mekasha C. 2013. Report on Chickpea Postharvest Loss Assessment Survey-Ethiopia. Ethiopian Institute Of Agricultural Research.

Mitiku D. 2011. Marketing of Kabuli and Desi Chickpeas By Smallholder Farmers In Eastern Shewa Zone.M.sc. An MSc Thesis Presented to the School of Graduate Studies of Haramaya University, Haramaya, Ethiopia.

Riziki, M.J., Saidi, M.P., Nkurumwa, S.M. and Ipomai, A.S. 2015. Determinants of choice of marketing outlets for African Indigenous Vegetables among the Agro-Pastoral Maasai of Narok and Kajiado Counties of Kenya. Journal of Economics and Sustainable Development,29-42.

Yamane Taro. 1967. Statistics: An introductory analysis. 2nd ed., New York: Harper and Row.

Yaregal tilahun. 2018. Potato market chain analysis: the case of sekela Woreda Amhara Region, Ethiopia. MSc Thesis. Haramaya University, Ethiopia. 45-56. 
